\title{
FAKTOR-FAKTOR YANG MEMPENGARUHI PROFITABILITAS PADA BANK MUAMALAT INDONESIA
}

\author{
Fathya Khaira Ummah ${ }^{1}$ dan Edy Suprapto ${ }^{2}$ \\ 1Program Studi Perbankan Syariah, Sekolah Tinggi Ekonomi Islam SEBI, \\ Depok, Jawa Barat. Email: khazira27@gmail.com \\ 2Program Studi Perbankan Syariah, Sekolah Tinggi Ekonomi Islam SEBI, \\ Depok, Jawa Barat. Email: edy.suprapto77@gmail.com
}

\begin{abstract}
ABSTRAK: Penelitian ini bertujuan untuk menguji dan menganalisis rasio keuangan terhadap profitabilitas Bank Muamalat Indonesia. Penelitian ini menggunakan metode vector error correction model dengan mengunakan data times series triwulan periode tahun Desember 2000 - September 2014. Variabel yang digunakan dalam penelitian ini adalah ROA, CAR, BOPO, NPF dan FDR. Hasil penelitian menunjukkan pada hasil VECM jangka pendek CAR dan NPF tidak berpengaruh signifikan terhadap profitabilitas BMI, sedangkan BOPO dan FDR berpengaruh negatif dan signifikan terhadap profitabilitas BMI. Artinya jika keduanya naik sebesar 1\% maka profitabilitas BMI akan menurun sebesar $2.4 \%$ dan 2.2\%. Hasil VECM jangka panjang menunjukkan bahwa CAR tidak berpengaruh signifikan terhadap profitabilitas bank. BOPO berpengaruh negatif dan signifikan terhadap profitabilitas bank, jika terjadi kenaikan BOPO sebesar satu persen maka profitabilitas BMI akan menurun sebesar $2.7 \%$. NPF berpengaruh negative dan signifikan terhadap profitabilitas BMI, jika terjadi kenaikan NPF sebesar satu persen maka profitabilitas BMI akan menurun sebesar 4.1\%. FDR berpengaruh negative dan signifikan terhadap profitabilitas BMI, jika terjadi kenaikan FDR sebesar satu persen, maka profitabilitas BMI akan menurun sebesar 5.4\% setiap triwulannya.
\end{abstract}

\section{Kata Kunci : ROA, CAR, BOPO, NPF, FDR, VECM dan Profitabilitas}

ABSTRACT: This study aims to examine and analyze financial ratios on profitability of Bank Muamalat Indonesia. Vector error correction model used in this study, by using the times series data is quarterly period of December 2000 - September 2014. The variables used in this study are ROA, CAR, ROA, $N P F$ and FDR. The results showed the results of short-term are CAR and NPF insignificant effect on the profitability of BMI, while ROA and FDR significant negative effect on profitability BMI. If there is an increase in ROA and NPF amounting to one percent of the profitability BMI will decrease by $2.4 \%$ and $2.2 \%$. However the long-term results showed that the CAR is insignificant effect on the profitability of banks. BOPO a significant negative effect on the profitability of banks, if there is an increase of one percent BOPO profitability BMI will decrease by 2.7\%. NPF and significant negative effect on the profitability of BMI, if there is an increase of one percent NPF profitability BMI will decrease by 4.1\%. FDR and significant negative effect on the profitability of BMI, if there is an increase of one per cent FDR, then the BMI profitability will decline by $5.4 \%$ on a quarterly basis.

Keywords: ROA, CAR, BOPO, NPF, FDR, VECM dan Profitability 


\section{PENDAHULUAN}

Bank Islam pertama, Bank Muamalat Indonesia. Didirikan pada tahun 1991 dan memulai kegiatan operasionalnya pada bulan Mei 1992. Pendirian Bank Muamalat Indonesia diprakarsai oleh Majelis Ulama Indonesia (MUI) yang kemudian di dukung oleh sekelompok pengusaha dan cendekiawan muslim. PT Bank Muamalat Indonesia (BMI) Tbk. merupakan bank pertama di Indonesia yang mengoperasikan kegiatannya berdasarkan prinsip-prinsip Islam. Sebagai suatu bank, BMI tetap melaksanakan operasionalnya sama dengan bank-bank konvensional lainnya selama tidak bertentangan dengan prinsip syariah. BMI tidak terlepas dari usaha-usaha untuk mencapai keuntungan yang akan dibagi hasilkan kepada para nasabahnya. Selain itu BMI juga tetap harus berpegangan pada prinsip Prudential Banking, yaitu prinsip kehati-hatian bank dalam mengoperasikan usahanya agar tetap dalam kondisi kinerja yang baik dan memenuhi kriteria bank sehat.

Pendirian perbankan syariah awalnya meragukan, banyak pihak beranggapan bahwa system perbankan bebas bunga (interest free) merupakan sesuatu yang tidak mungkin dan tidak lazim. Ketika Indonesia dilanda krisis moneter 1997 dan adanya kebijakan Bank Indonesia untuk menerapkan tigh money policy dengan menetapkan bunga simpanan hingga 70\%, membuat dunia perbankan panik. Di sisi lain Bank Indonesia berhasil menyedot uang masuk kembali sistem perbankan, sehingga bisa menekan spekulasi yang meningkatkan pembelian dollar. Dampak negative spread tersebut ternyata tidak mempengaruhi kinerja Bank Muamalat yang menjalankan zero interest atau tanpa bunga. Bank Muamalat terhindar dari kerugian akibat spekulasi di pasar uang, kerena tidak adanya transaksi derivative. Dengan kenyataan ini bukan berarti Muamalat tidak terkena dampak dari krisis ekonomi, Muamalat memang bisa bertahan dari krisis namun kinerjanya mengalami penurunan. Pada tahun 1998, Muamalat mengalami kerugian operasional hingga Rp.105 milyar. Namun dengan kinerja yang mereka tingkatkan maka Bank Muamalat mampu mengembalikan modal yang merosot.

Mengukur kinerja perusahaan yang nota bene adalah profit motif dapat digunakan analisis profitabilitas. Profitability analisys yang implementasinya adalah profitability ratio disebut juga operating ratio, ada dua tipe rasio yakni margin on sale dan return on asset. Profit margin untuk mengukur kemampuan perusahaan untuk mengendalikan pengeluaran yang berhubungan dengan penjualan, melalui gross profit margin, operating profit margin dan net profit margin (Shapito, 2000). Dengan ini hubungan antara Return On Asset dan Shareholder equity ada dua ukuran yakni Return On Asset (ROA) dan Return On Equity (ROE). ROA memfokuskan kemampuan perusahaan untuk memperoleh earning dalam operasi perusahaan, sedangkan ROE hanya mengukur return yang diperoleh dari investasi pemilik perusahaan dalam bisnis tersebut (Marwadi, 2005 dikutip oleh Batuara, 2013). Bank Indonesia juga lebih mengutamakan nilai profitabilitas suatu bank yang diukur dengan ROA dibandingkan dengan ROE karena Bank Indonesia lebih mengutamakan nilai profitabilitas suatu bank yang diukur dengan asset dananya sebagian besar berasal dari simpanan masyarakat sehingga ROA lebih mewakili dalam mengukur tingkat profitabilitas bank (Dendawijaya, 2001 dikutip oleh Arimi, 2012).

Sejak berdirinya, asset BMI mengalami peningkatan, hal ini terlihat dari data dibawah ini: 
Grafik 1. 1 Total Asset yang ada Tiap Tahun

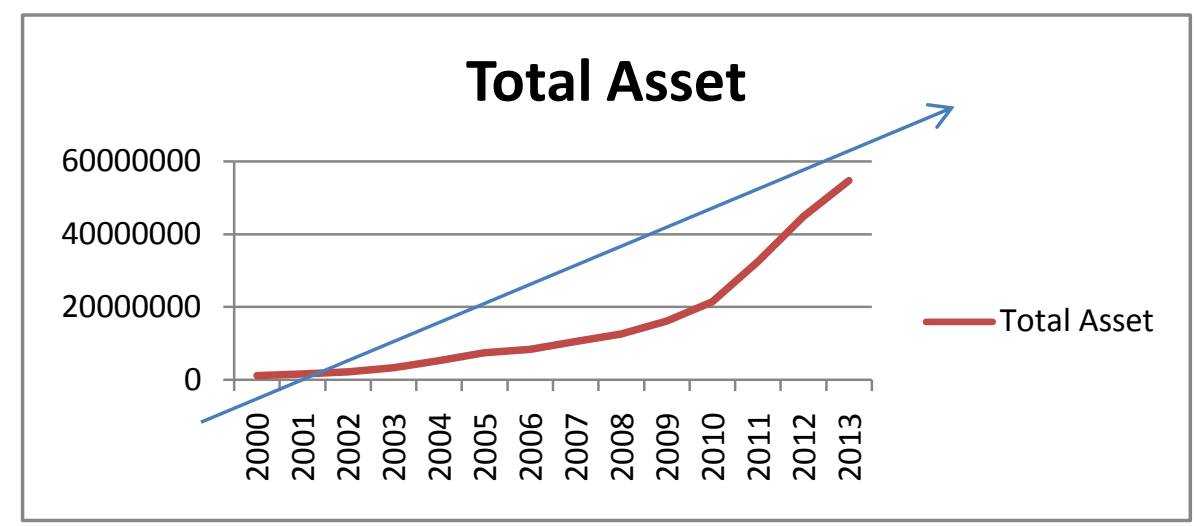

Sumber : Laporan Keuangan BMI, (data diolah)

Pergerakan yang terjadi pada grafik diatas menunjukkan bahwa tiap tahunnya aset BMI mengalami peningkatan tiap tahun pada akhir tahun atau bulan Desember dalam jumlah jutaan rupiah. Peningkatan yang terjadi terbilang sangat signifikan meningkat tiap tahunnya, dengan ini memungkinkan penurunan terhadap ROA juga semakin drastis tiap tahunnya. Sedangkan, pergerakan ROA relative stabil. Meskipun diawal tahun 2000 menuju 2001 mengalami kenaikan yang signifikan. Seterusnya tingkat ROA berada pada kisaran 2\% sampai 3\% dalam kurun waktu 2002 sampai 2009. Kemudian mengalami penurunan pada tahun 2010 sampai 20013 pada kisaran $1.5 \%$ sampai $2 \%$. Dan yang menarik pada tahun 2014 ROA melonjak signifikan diatas 4\%. Sebagaimana dapat dilihat pada grafik dibawah ini.

Grafik 1. 2 Peningkatan Terhadap ROA Tiap Tahun

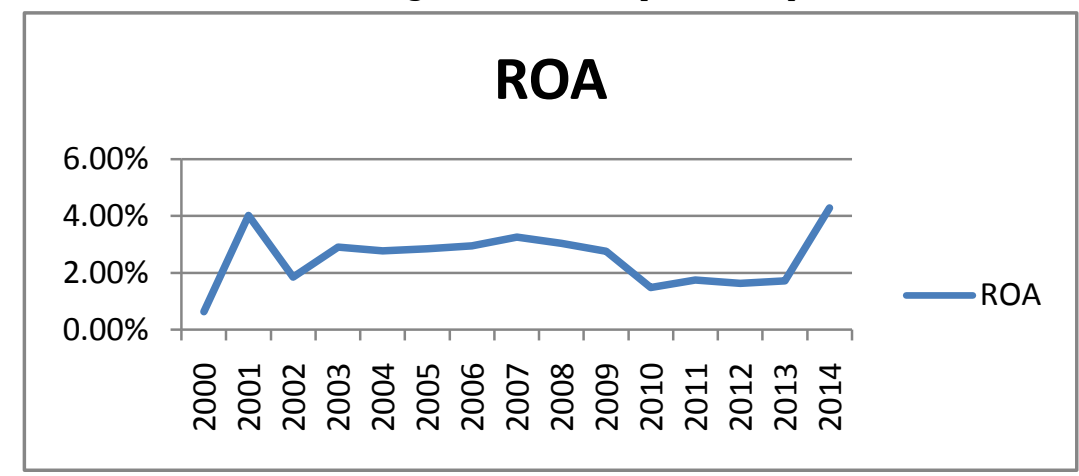

Sumber : Laporan Keuangan Bank Muamalat Indonesia (data diolah)

Sebaliknya, kinerja Bank Muamalat Indonesia (BMI) juga dapat dilihat dari total asset yang dimiliki oleh bank tersebut. Hal ini dapat dilihat pada Grafik 1.1 yang menggambarkan pergerakan aset Bank Muamalat Indonesia tiap tahunnya. Pada data yang telah tergambar pada grafik di bawah, secara signifikan total aset Bank Muamalat Indonesia meningkat dari tahun ke tahun. Berbeda dengan peningkatan yang terjadi pada ROA, total aset jauh lebih signifikan meningkatnya dibandingkan dengan peningkatan 
yang terjadi pada rasio ROA. ROA penting bagi bank karena digunakan untuk mengukur efektivitas perusahaan di dalam menghasilkan keuntungan dengan memanfaatkan aktiva yang dimilikinya. ROA merupakan rasio antara laba sesudah pajak terhadap total aset. Semakin besar ROA menunjukkan kinerja perusahaan semakin baik, karena tingkat pengmbalian (return) semakin besar (Suad Husnan, 1998; dikutip oleh Adyani, 2011). Dapat dikatakan bahwa data yang tergambarkan ROA berpengaruh negatif terhadap total aset yang di miliki BMI.

Perkembangan kinerja Bank Muamalat Indonesia dapat dilihat dari beberapa indikator terutama pada rasio keuangan yang terbagi dalam tiga rasio yaitu : Rasio Solvabilitas, Rasio Rentabilitas dan Rasio Likuiditas. Sebenarnya, penelitian tentang profitabilitas BMI sudah banyak dilakukan. Sebagai contoh Amsaroh (2012), Pratiwi dan Astutiningsih (2009), Martadireja (2014), Ananda, SE (2009), Arianti (2011) mengkaji kesehatan BMI dengan menggunakan metode regresi berganda. Dahlia (2012), Maharani (2010), Akhirudin (2014), Widodo (2014), Rosada (2013) mengkaji kinerja BMI dengan dengan menggunakan Independen Sample T-test. Damastuti (2010) mengkaji kinerja BMI dengan menggunakan metode Value Added Approach.

Dari hasil penelitian diatas, menunjukkan bahwa ada beberapa faktor yang digunakan dalam penelitian sebelumnya hasil penelitian yang berbeda-beda. Faktor pada rasio CAR semakin besar, maka semakin besar ROA. Menurut Amsaroh (2012), Pratiwi dan Astutiningsih (2009), Martadireja (2014), Puspitasari (2009) menyatakan bahwa faktor pada rasio CAR menggunakan metode regresi linier berganda sangat signifikan terhadap kinerja Bank Muamalat Indonesia. Berbanding terbalik dengan pendapat menurut Ananti (2011) menyatakan dalam hasil penelitiannya bahwa faktor rasio CAR dengan menggunakan regresi linier berganda tidak signifikan terhadap kinerja Bank Muamalat Indonesia. Faktor pada rasio CAR menurut Maharani (2010), Akhirudin (2014), Rosada (2013) menyatakan dalam penelitiannya bahwa faktor rasio CAR menggunakan metode Independent Sample T-test berpengaruh signifikan terhadap kinerja Bank Muamalat Indonesia. Sedangkan menurut Dahlia (2012), Widodo (2014) menyatakan bahwa faktor rasio CAR dengan menggunakan metode Independent Sampel T-test tidak berpengaruh signifikan terhadap kinerja Bank Muamalat Indonesia.

Untuk melihat variabel kedua yaitu faktor pada rasio NPF menurut Amsaroh (2012), dan Martadireja (2014) menyatakan bahwa faktor rasio pada NPF dengan menggunakan metode regresi linier berganda berpengaruh signifikan terhadap kinerja Bank Muamalat Indonesia. Sedangkan menurut Arianti (2011) menyatakan bahwa faktor rasio NPF dengan menggunakan metode regresi linier berganda tidak berpengaruh signifikan terhadap kinerja Bank Muamalat Indonesia. Menurut Rosada (2013) faktor pada rasio NPF dengan menggunakan metode Independent Sample T-test sangat berpengaruh signifikan terhadap kinerja Bank Muamalat Indonesia, sedangkan menurut Akhirudin (2014) dengan menggunakan Independent Sample T-test faktor rasio NPF tidak berpengaruh signifikan terhadap kinerja Bank Muamalat Indonesia.

Begitu pula dengan faktor rasio yang selanjutnya adalah BOPO menurut Pratiwi dan Astutiningsih (2009), Puspitasari (2009) menyatakan dengan menggunakan metode regresi linier berganda sangat berpengaruh signifikan terhadap kinerja bank. Menurut Dahlia (2012), Maharani (2010), Akhirudin (2014), Widodo (2014) menyatakan bahwa BOPO berpengaruh signifikan terhadap kinerja keuangan Bank Muamalat Indonesia. 
Jurnal Ekonomi dan Perbankan Syariah

Vol. 3. No.1, April 2015: 1-17, ISSN (cet): 2355-1755

Sedangkan menurut Damastuti (2010) menggunakan metode Value Added Aprroach tidak berpengaruh signifikan terhadap kinerja keuangan Bank Muamalat Indonesia.

Dilanjutkan dengan rasio FDR juga merupakan salah satu faktor yang mempengaruhi kinerja suatu bank. Menurut Amsaroh (2012) berpendapat dalam penelitiannya bahwa menggunakan metode regresi linier berganda sangat berpengaruh signifikan terhadap kinerja bank. Begitu pula menurut Dahlia (2012), Widodo (2014), Rosada (2013) berpendapat bahwa dengan menggunakan metode Independent Sample Ttest berpengaruh signifikan terhadap kinerja bank. Sedangnkan menurut Maharani (201), dan Akhirudin (2014) dengan menggunakan metode Independent Sample T-test tidak berpengaruh signifikan terhadap kinerja bank.

\section{TELAAH PUSTAKA}

\section{Definisi Perbankan Syariah}

Menurut Undang - Undang No. 21 Tahun 2008 tentang perbankan syariah. Pengertian bank syariah adalah bank yang menjalankan kegiatan usahanya berdasarkan prinsip-prinsip syariah dan menurut jenisnya terdiri atas Bank Umum Syariah, Usaha Unit Syariah (UUS), dan Bank Pembiayaan Rakyat Syariah (Soemitra, 2009). Dalam peristilahan internasional bank syariah dikenal sebagai Islamic Banking atau juga disebut dengan interest-free banking. Peristilahan dengan menggunakan kata Islamic tidak dapat dilepas dari asal-usul sistem perbankan syariah itu sendiri yaitu penyedia jasa transaksi keuangan yang dilaksanakan sejalan dengan nilai moral dan prinsip syariah islam (Muhammad, 2004 dikutip oleh Zulmaita, 2011).

Pengertian bank syariah dibagi menjadi dua : (1) bank islam adalah bank yang beroperasi sesuai dengan prinsip-prinsip syariah Islam ; (2) bank yang tata cara beroperasinya mengacu kepada ketentuan-ketentuan Al-Qur'an dan Hadist; sementara bank yang beroperasi sesuai dengan prinsip Islam adalah bank yang dalam beroperasinya itu mengikuti ketentuan-ketentuan syariah Islam, khususnya yang menyangkut tata cara bermuamalah secara Islam. Dikatakan lebih lanjut, dalam tata cara bermuamalah itu dijauhi praktek-praktek yang dikhawatirkan mengandung unsur-unsur riba untuk diisi dengan kegiatan-kegiatan investasi atas dasar bagi hasil dan pembiayaan perdagangan (Perwataatmaja dan Antonio, 1997 dikutip oleh Yusdani, 2005).

Dari uraian diatas dapat ditarik kesimpulan bahwa bank syariah adalah bank yang melakukan aktivitasnya dalam pemberian jasa dan lainnya berdasarkan prinsip syariah Islam, seperti menghindari penggunaan instrument bunga ( $r i b a$ ) dan beroperasi dengan prinsip bagi hasil (profit and loss sharing). Hal inilah yang membedakan sistem perbankan syariah dengan sistem perbankan konvensional.

\section{Rasio Keuangan Bank}

Secara umum rasio keuangan merupakan penyederhanaan dari informasi laporan keuangan bank. Agar laporan keuangan dapat dibaca sehingga menjadi berarti maka perlu dilakukan analisis terlebih dahulu. Analisis yang digunakan adalah dengan menggunakan rasi-rasio keuangan sesuai standar yang berlaku. Analisis rasio dapat digunakan sebagai alat untuk mengevaluasi kinerja dan kondisi keuangan perusahaan.

Dalam mengadakan interpretasi dan analisa laporan finansial suatu perusahaan, diperlukan adanya ukuran atau "yard-stick" tertentu. Ukuran yang sering digunakan 
dalam analisis finansial adalah "rasio". Pengertian rasio itu sebenarnya hanyalah alat yang dinyatakan dalam "arithmatical terms" yang dapat digunakan untuk menjelaskan hubungan antara dua macam data finansial (Rianto, 2001 dikutip oleh Hardiyanti, 2012).

Analisis rasio finansial pada dasarnya dapat dilakukan dengan dua macam perbandingan, yaitu :

a. Membandingkan rasio sekarang (present rasio) dengan rasio-rasio dari waktuwaktu yang lalu (rasio historis) atau dengan rasio-rasio yang diperkirakan untuk waktu-waktu yang akan datang dari perusahaan yang sama.

b. Membandingkan rasio-rasio dari suatu perusahaan (rasio perusahaan / company rasio) dengan rasio-rasio semacam dari perusahaan yang lain yang sejenis atau industri (rasio industri / rasio rata-rata / ratio standard) untuk waktu yang sama.

\section{Jenis-Jenis Rasio Keuangan}

Dilihat dari sumbernya dari mana rasio itu dibuat, maka rasio dapat digolongkan dalam tiga golongan, yaitu :

a. Rasio-rasio neraca (balance sheet ratio), ialah rasio-rasio yang disusun dari data yang berasal dari neraca, misalnya currents assets, acid-test ratio, current assets to total assets ratio, current liabilities to total assets ratio dan lain sebagainya.

b. Rasio-rasio laporan laba dan rugi (income statement ratio), ialah rasio-rasio yang disusun dari data yang berasal dari income statement, misalnya gross profit margin, net operating margin, operating ratio dan lain sebagainya.

c. Rasio-rasio antar laporan (inter-statement ratio), ialah rasio-rasio yang disususn dari data yang berasal dari neraca dan data lainnya berasal dari income statement, misalnya assets turnover, inventory turnover, receivables turnover, dan lain sebagainya.

Profitabilitas adalah kemampuan perusahaan memperoleh laba dalam hubungannya dengan penjualan, total aktiva, maupun modal sendiri . Rasio profitabilitas dimaksudkan untuk mengukur efisiensi penggunaan aktiva perusahaan. Profitabilitas menjadi begitu penting untuk mengetahui apakah perusahaan telah menjalankan usahanya secara efisien atau tidak. Efisiensi sebuah usaha baru dapat diketahui setelah membandingkan laba yang diperoleh dengan aktiva atau modal yang menghasilkan laba tersebut. Profitabilitas atau rentabilitas digunakan untuk mengukur efisiensi penggunaan modal dalam suatu perusahaan dengan membandingkan antara laba dan modal yang digunakan dalam operasi, oleh karena itu keuntungan yang besar tidak menjamin atau bukan merupakan ukuran bahwa perusahaan tersebut rentable (Munawir, 2001:51 dikutip oleh Wibowo, 2007).

Ang (1997) dikutip oleh Handoko (2014) mengungkapkan bahwa rasio profitabilitas dan rasio rentabilitas menunjukkan keberhasilan perusahaan dalam menghasilkan keuntungan. Kemampuan perusahaan untuk menghasilkan laba dalam kegiatan operasinya merupakan fokus utama dalam penilaian prestasi perusahaan. Selain merupakan indikator kemampuan perusahaan dalam memenuhi kewajiban bagi para penyandang dananya, laba perusahaan juga merupakan elemen dalam menentukan nilai perusahaan. Analisis profitabilitas menekankan pada kemampuan perusahaan dalam mendayagunakan kekayaan yang ada untuk menghasilkan laba selang periode tertentu 
Jurnal Ekonomi dan Perbankan Syariah

Vol. 3. No.1, April 2015: 1-17, ISSN (cet): 2355-1755

yang diukur melalui rasio-rasio profitabilitas (Riyanto, 1999 dikutip oleh Hermuningsih, 2013).

Menurut Bank Indonesia, ROA merupakan perbandingan antara laba sebelum pajak dengan rata-rata total aset dalam suatu periode. Rasio ini dapat dijadikan sebagai ukuran kesehatan keuangan. Rasio ini sangat penting, mengingat keuntungan yang diperoleh dari penggunaan aset dapat mencerminkan tingkat efisiensi usaha suatu bank. Dalam kerangka penilaian kesehatan bank, BI akan memberikan score maksimal 100 (sehat) apabila bank memiliki ROA > 1,5\% (Hasibuan,2006 dikutip oleh Arimi, 2012).

ROA dipilih sebagai indikator pengukur kinerja keuangan perbankan karena ROA digunakan untuk mengukur efektifitas perusahaan di dalam menghasilkan keuntungan dengan memanfaatkan aktiva yang dimilikinya. ROA dapat membantu perusahaan yang telah menjalankan praktik akuntansi dengan baik untuk dapat mengukur efisiensi pengguna modal yang menyeluruh, yang sensitif terhadap setiap hal yang mempengaruh keadaan keuangan perusahaan sehingga dapat diketahui posisi perusahaan terhadap industri. Hal ini merupakan salah satu langkah dalam perencanaan strategi. ROA dirumuskan sebagai berikut :

$$
\text { ROA }=\frac{\text { Laba Sebelum Pajak }}{\text { Total Aset }}
$$

Menurut Kusno dan Achmad (2003) pada kutipan Sukmawijaya (2011) CAR merupakan rasio permodalan yang menunjukkan kemampuan bank dalam menyediakan dana untuk keperluan pengembangan usaha serta menampung kemungkinan risiko kerugian yang diakibatkan dalam operasional bank. Semakin besar rasio tersebut akan semakin baik posisi modal. CAR juga merupakan indikator terhadap kemampuan bank untuk menutupi penurunan aktivanya sebagai akibat dari kerugian-kerugian bank yang disebabkan oleh aktiva yang berisiko. Semakin tinggi CAR maka semakin baik kemampuan bank tersebut untuk menanggung risiko dari setiap kredit atau aktiva produktif yang berisiko. jika nilai CAR tinggi, maka bank tersebut mampu membiayai kegiatan operasional dan memberikan kontribusi yang cukup besar bagi profitabilitas. CAR dapat dirumuskan sebagai berikut: $\quad C A R=\frac{\text { Modal }}{\text { ATMR }}$

Menurut surat Edaran BI No. 3/30DPNP tanggal 14 Desember 2001, BOPO diukur dari perbandingan antara biaya operasional terhadap pendapatan operasional. Biaya operasi merupakan biaya yang dikeluarkan oleh bank dalam rangka menjalankan aktivitas usaha pokoknya (biaya tenaga kerja, biaya pemasaran dan biaya operasi lainnya). Rasio BOPO bertujuan untuk mengukur kemampuan pendapatan operasional dalam menutup biaya operasional. Jika rasio BOPO semakin meningkat mencerminkan kurangnya bank dalam mengelola usahanya (SE.Intern BI, 2004) Bank Indonesia menetapkan rasio BOPO adalah dibawah 90\%. Karena jika rasio BOPO melebihi 90\% hongga mendekati $100 \%$ maka bank tersebut dapat dikategorikan tidak efisien dalam menjalankan kegiatan operasionalnya.

BOPO merupakan upaya bank untuk meminimalkan resiko operasional, yang merupakan ketidakpastian mengenai kegiatan usaha bank. Resiko operasional berasal dari kerugian operasional bila terjadi penurunan keuntungan yang dipengaruhi oleh 
struktur biaya operasional bank, dan kemungkinan terjadinya kegagalan atas jasa-jasa dan produk-produk yang ditawarkan. BOPO dapat dirumuskan sebagai berikut:

$$
B O P O=\frac{\text { Beban Operasional }}{\text { Pendapatan Operasional }}
$$

dengan kata lain NPF merupakan tingkat kredit macet pada bank tersebut. NPF diketahui dengan cara menghitung Pembiayaan Non Lancar terhadap Total pembiayaan. Apabila semakin rendah NPF maka bank tersebut akan semakin naik keuntungannya, sebaliknya bila tingkat NPF tinggi bank tersebut akan mengalami kerugian yang diakibatkan tingkat pengembalian kredit macet. Adapun cara ,menghitung NPF adalah sebagai berikut :

$$
N P F=\frac{\text { Pembiayaan Tidak Lancar }}{\text { Total Pembiayaan }}
$$

Standar yang digunakan Bank Indonesia untuk FDR adalah 80\% hingga 110\%. Jika angka FDR suatu bank berada pada angka di bawah 80\% (misal 60\%), maka dapat disimpulkan bahwa bank tersebut hanya dapat menyalurkan sebesar $60 \%$ dari seluruh dana yang berhasil dihimpun. Karena fungsi utama dari bank adalah sebagai intermediasi (perantara) antara pihak yang kelebihan dana dengan pihak yang kekurangan dana, maka dengan rasio FDR $60 \%$ berarti $40 \%$ dari seluruh dana yang dihimpun tidak tersalurkan kepada pihak yang membutuhkan, sehingga dapat dikatakan bahwa bank tersebut tidak menjalankan fungsinya dengan baik. Kemudian jika rasio FDR bank mencapai lebih dari $110 \%$, berarti total pembiayaan yang diberikan bank tersebut melebihi dana yang dihimpun. Oleh karena dana yang dihimpun dari masyarakat sedikit, maka bank dalam hal ini juga dapat dikatakan tidak menjalankan fungsinya sebagai pihak intermediasi (perantara) dengan baik. Semakin tinggi FDR menunjukkan semakin riskan kondisi likuiditas bank, sebaliknya semakin rendah FDR menunjukkan kekurangan efektivitas bank dalam menyalurkan pembiayaan. Jika FDR bank berada pada standar yang ditetapkan oleh Bank Indonesia, maka laba yang diperoleh bank tersebut akan meningkat (dengan asumsi bank tersebut mampu menyalurkan pembiayaan dengan efektif) . Rasio ini di rumuskan sebagai berikut :

\section{Penelitian Terdahulu}

$$
F D R=\frac{\text { Total Pembiayaan }}{\text { Dana Pihak Ketiga dan Ekuitas }}
$$

Amsaroh (2012) melakukan penelitian tentang tingkat kesehatan bank berdasarkan factor permodalan, kualitas aset, rentabilitas, dan likuiditas pada BMI. Variabel yang digunakan dalam penelitian ini adalah CAR, NPF, ROA, dan FDR. Metode yang digunakan adalah persamaan regresi linier berganda. Hasil penelitian menyatakan faktor permodalan pada rasio CAR tahun 2009-2011 dinyatakan sehat, faktor kualitas pada rasio NPF tahun 2009-2011 dinyatakan sehat, faktor rentabilitas pada rasio ROA tahun 2009 kurang sehat sedangkan tahun 2010-2011 dinyatakan cukup sehat, faktor Likuiditas pada rasio FDR tahun 2009-2011 dinyatakan sehat.

Astutiningsih (2009), untuk mengetahui kinerja keuangan PT. Bank Muamalat IndonesiaTbk periode 2006-2008. Variabel yang digunakan BOPO, CAR, DTE, dan LTDTA. Metode yang digunakan yaitu regresi linier berganda. Hasil penelitian yaitu PT Bank Muamalat Indonesia mampu menghasilkan tingkat laba yang baik, walaupun mengalami penurunan efesiensi kinerja pada rasio BOPO di tahun 2007, yang semula 69,41\% 
menjadi 71,73\%. Kinerja pada solvabilitas rasio CAR menurun pada tahun 2007 dari $14,56 \%$ menjadi $10,79 \%$, rasio DTE masih cukup tingg. Pada rasioa LTDTA mengalami kenaikan pada tahun 2008 yang berarti kinerja LTDTA menurun. Jadi dapat disimpulkan bahwa kinerja keuangan PT. Bank Muamalat Indonesia Tbk dapat dinilai sehat.

Martadireja (2014) melakukan penelitian tentang efek dari NPF, CAR, NIM, terhadap kenaikan profitabilitas bank pada Bank Muamalat Indonesia. Variabel yang digunakan NPF, CAR, NIM, dan ROA. Metode yang digunakan ialah Analisis Regresi Berganda. Hasil dari hipotesis secara simultan test F diketahui NPF, CAR dan NIM mengalami kenaikan yang signifikan terhadap profitabiltas bank pada BMI dengan signifikan level dari 0.00, sedangkan hasil dari hipotesis T-test BMI diketahui CAR dan NIM mengalami kenaikan yang signifikan terhadap profitabilitas, sedangkan NPF tidak signifikan.

Puspitasari (2009) melakukan penelitian dengan menggunakan indicator rasio keuangan pada bank syariah terhadap profitabilitas (ROA). Metode yang digunakan adalah Regresi linier berganda. Variable yang digunakan adalah CAR, NPL, PDN, NIM, BOPO, LDR, dan suku bunga SBI. Diketahui hasil dari penelitian adalah CAR signifikan positf terhadap ROA, NPL signifikan negatif terhadap ROA, PDN tidak berpengaruh, NIM berpengaruh positif, BOPO berpengaruh negatif, LDR berpengaruh signifikan positif, sedangkan suku bunga SBI tidak berpengaruh.

Ananda (2009) menganalisa dan menguji pengaruh indicator krisis keuangan global pada Bank Muamalat Indonesia. Variable yang digunakan adalah tingkat inflasi, tingkat suku bunga BI rate dan tingkat profitabilitas ROE. Metode yang digunakan yaitu Regresi berganda, Kolerasi berganda, dan Koefisien determinasi. Hasil yang diperoleh bahwa secara simultan variabel independent (tingkat inflasi, tingkat suku bunga, dan total pendapatan yang dibagi hasilkan) mampu mempengaruhi variabel dependent yaitu tingkat profitabilitas (ROE) BMI. Sedangkan secara parsial, masing-masing variabel independent tidak mempengaruhi tingkat profitabilitas BMI selama periode krisis. Dalam variabel tingkat suku bunga, hal ini diduga karena dalam system dan teknis perbankan syariah tidak dkenal adanya interest rate yang menyebabkan terjadinya negative spread. Dari sisi tingkat inflasi adalah dikarenakan tingkat NPF dalam perbankan syariah yang masih dibawah 5\% khususnya BMI sehingga tidak sampai menyebabkan kredit macet yang tinggi dan mempengaruhi tingkat pengembalian keuntungan. Sedangkan variabel ketiga yaitu total pendapatan yang dibagi hasilkan tidak mempengaruhi profitabilitas BMI dikarenakan kurangnya sosialisasi terhadap dampak bunga bank oleh pemerintah juga penyuluhan mengenai perbankan syariah sehingga menyebabkan minimnya pemahaman masyarakat terhadap system dan teknis perbankan syariah.

Arianti (2011) tujuan penelitian untuk mengetahui sejauh mana hubungan variabel DPK, CAR, NPF dan ROA terhadap pembiayaan perbankan syariah. Metode Analisis yang digunakan adalah Regresi Berganda dengan tingkat signifikansi 5\%. Hasil analisis menunjukkan bahwa secara parsial hanya DPK yang berpengaruh signifikan positif terhadap pembiayaan, sedangkan CAR, NPF, dan ROA tidak berpengaruh terhadap pembiayaan. Secara simultan variable DPK, CAR, NPF, dan ROA berpengaruh signifikan terhadap pembiayaan. Hal ini dibuktikan dengan nilai sig-F 0,000 yang lebih kecil dari signifikansi 5\%. Kemampuan prediksi dari keempat variabel tersebut terhadap 
pembiayaan adalah 98,9\% sebagaimana ditunjukkan oleh besarnya adjusted R2, sedangkan sisanya $1,1 \%$ dipengaruhi oleh factor lain yang tidak dimasukkan kedalam model penelitian.

Dahlia (2012) melakukan penelitian secara empiris tentang perbedaan kinerja keuangan antara PT Bank Syariah Mandiri dengan PT Bank Muamalat Indonesia selama periode 2005-2010. Variabel yang digunakan dalam penelitian ini adalah CAR, NPM, ROA, BOPO, dan LDR. Metode yang digunakan adalah metode Independent sample t-test. Hasil penelitian terdapat perbedaan yang signifkan untuk rasio NPM, BOPO, LDR. Sedangkan pada rasio CAR dan ROA tidak terdapat perbedaan yang signifikan. Kinerja keuangan Bank Syariah Mandiri lebih baik dari segi permodalan terhadap CAR dan Rasio Efisiensi terhadap BOPO sedangkan Bank Muamalat Indonesia lebih baik kinerja dari segi Rentabilitas terhadap ROA, NPM, dan Rasio Likuiditas terhadap LDR.

Maharani (2010) penelitian yang dilakukan yaitu membandingkan kinerja keuangan perbankan syariah (BMI) dengan perbankan konvensional (BRI) pada periode 2003-2008. Variabel yang digunakan yaitu CAR, ROA, ROE, BOPO dan LDR. Metode yang digunakan dalam penelitian adalah Independent sample t-Test. Hasil pengujian menunjukkan bahwa terdapat perbedaan yang signifikan antara bank yang sehat (berkinerja baik) dengan bank yang tidak sehat (berkinerja tidak baik). ROA menghasilkan F terbesar 60,314 dan nilai Wilk's Lambda terkecil 0,142, serta tingkat signifikan < 5\%, LDR menghasilkan F terkecil 11,930 dan nilai Wilk's Lambda terbesar 0,456 , serta tingkat signifikansi $<5 \%$. Dihasilkan persamaan diskriminan sebesar $100 \%$ untuk kinerja baik dan kinerja tidak baik. Disimpulkan kinerja keuangan perbankan syariah tdak sama dengan kinerja keuangan bank konvensional.

Akhirudin (2014) menganalisis perbandingan kinerja keuangan BMI dan Bank Tabungan Negara. Variabel yang digunakan adalah rasio-rasio CAR, ROA, ROE, BOPO, LDR dan NPL. Metode yang digunakan adalah uji beda dua rata-rata (Uji t). Hasil penelitian dilihat dari rasio CAR kinerja keuangan BMI dan BTN tidak terdapat perbedaan, sedangkan dilihat pada rasio ROA, ROE, BOPO, LDR, NPL kinerja keuangan BMI dan BTN terdapat perbadaan. Jika dilihat rata-rata rasio, pada rasio ROE dan NPL dapat diketahui bahwa BMI mempunyai kinerja yang lebih baik dibandingkan dengan kinerja BTN. Sedangkan pada rasio CAR, ROA, BOPO, dan LDR dapat diketahui bahwa BTN mempunyai kinerja yang lebih baik dibandingkan dengan kinerja BMI.

Widodo (2014) meneliti dan membuktikan secara empiris tentang perbedaan kinerja keuangan antara PT Bank Muamalat Indonesia dengan PT Bank Mega selama periode 2008-2013. Variabel yang digunakan adalah CAR, NPM, ROA, BOPO, LDR. Metode yang digunakan dengan uji Independent Sample T-test. Hasil penelitian menunjukkan bahwa terdapat perbedaan yang signifikan untuk rasio NPM, BOPO, LDR. Sedangkan pada rasio CAR dan ROA tidak terdapat perbedaan yang signifikan. Kinerja keuangan BMI lebih baik dari segi Permodalan terhadap CAR dan Rasio Efensiensi terhadap BOPO, sedangkan Bank Mega lebih baik kinerjanya dari segi Rentabilitas terhadap ROA, NPM, dan Rasio Likuiditas terhadap LDR.

Rosada (2013:3) meneliti tentang efek dari kinerja keuangan dengan variabel rasio CAR, ROA, NPL dan LDR dalam kinerja keuangan terhadap ROA. Hasil dari penelitiannya "study showed that : 1) there is a significant effect between CAR, ROA, NPL and LDR together on ROA, and 2) there is significant effect on ROA partially. Implementation is 
that variable can be input CAR, ROA, NPL, and LDR be relied upon, either by the management company in the management of the company, as well as by investors in determining the investment stategy".

Damastuti (2010) menganalisis perbedaan kinerja keuangan bank syariah dengan menggunakan pendekatan laba rugi dan nilai tambah berdasarkan rasio keuangan. Variabel yang digunakan terdiri dari ROA, ROE, rasio perbandingan antara total laba bersih dengan total aktiva produktif, NPM, dan BOPO. Metode yang digunakan yaitu Income Statement Approach dan Value Added Approach. Hasil penelitian menunjukkan bahwa rata-rata rasio keuangan terdapat perbedaan yang signifikan antara Income Statement Approach dan Value Added Approach, sedangkan pada rasio BOPO antara Income Statement Approach dan Value Added Approach tidak terdapat perbedaan. Akan tetapi bila dilhat secara keseluruhan tingkat profitabilitas menunjukkan adanya perbedaan yang signifikan antara Income Statement Approach dan Value Added Approach.

Berdasar pemaparan penelitian sebelum diatas dapat diringkas dalam tabel 2.1 dibawah ini:

Tabel 2.1 Penelitian Terdahulu pada Bank Muamalat Indonesia

\begin{tabular}{|c|c|c|c|c|}
\hline \multirow{2}{*}{ Nama } & \multicolumn{4}{|c|}{ Variabel } \\
\cline { 2 - 5 } & CAR & NPF & BOPO & FDR \\
\hline Amsaroh (2012) & $\sqrt{ }$ & $\sqrt{ }$ & - & $\sqrt{ }$ \\
\hline Asttutiningsih (2009) & $\sqrt{ }$ & - & $\sqrt{ }$ & - \\
\hline Martadireja (2014) & $\sqrt{ }$ & $\sqrt{ }$ & - & - \\
\hline Ananti (2011) & $\mathrm{X}$ & $\mathrm{X}$ & - & - \\
\hline Dahlia (2012) & $\mathrm{X}$ & - & $\sqrt{ }$ & $\sqrt{ }$ \\
\hline Maharani (2010) & $\sqrt{ }$ & - & $\sqrt{ }$ & $\mathrm{X}$ \\
\hline Akhirudin (2014) & $\sqrt{ }$ & $\mathrm{X}$ & $\sqrt{ }$ & $\mathrm{X}$ \\
\hline Widodo (2014) & $\mathrm{X}$ & - & $\sqrt{ }$ & $\sqrt{ }$ \\
\hline Rosada (2013) & $\sqrt{ }$ & $\sqrt{ }$ & - & $\sqrt{ }$ \\
\hline Puspitasari (2009) & $\sqrt{ }$ & - & $\sqrt{ }$ & - \\
\hline Damastuti (2010) & - & - & $\mathrm{X}$ & - \\
\hline
\end{tabular}

Keterangan:

$\sqrt{=}$ signifikan $X=$ tidak signifikan

Di atas adalah beberapa bentuk penelitian yang pernah dilakukan pada Bank Muamalat Indonesia dalam menganalisis kinerja keuangan pada bank tersebut. Namun ada beberapa penelitian yang hampir sama dalam mengukur kinerja keuangan pada bank syariah lainnya, terutama pada bank umum syariah. Beberapa bentuk jurnal dan penelitian terdahulu yang ada dalam berbagai metode yang sama dalam mengukur kinerja keuangan bank tersebut yaitu :

Dewi (2010) menganalisis pengaruh variabel rasio CAR, FDR, NPF, REO terhadap ROA. Metode yang digunakan ialah Analisis Regresi Linier Berganda dengan memnggunakan SPSS. Dari hasil uji hipotesis CAR tidak berpengaruh signifikan terhadap ROA pada Bank Syariah di Indonesia. FDR tidak berpengaruh signifikan terhadap ROA. NPF berpengaruh signifikan negatif terhadap ROA. REO berpengaruh sgnifikan negative terhadap ROA pada Bank Syariah di Indonesia. 
Setiawan (2009) penelitian dilakukan untuk menguji pengaruh factor makroekonomi yang diukur dengan pertumbuhan inflasi dan GDP, pangsa pasar yang diukur dengan pangsa pembiayaan dan karakterisrik bank yang diukur dengan variable CAR, FDR, NPF, BOPO, SIZE terhadap ROA Bank Syariah di Indonesia. Metode yang digunakan adalah regresi linier berganda. Hasil penelitian ini menunjukkan bahwa variable pertumbuhan inflasi dan pertumbuhan GDP tidak menunjukkan pengaruh signifikan terhadap ROA. Variable FDR, pangsa pasar, CAR berpengaruh positif signifikan terhadap ROA, sedangkan variable NPF, BOPO, dan SIZE berpengaruh negatif signifikan terhap ROA. Kemampuan prediksi dari ke delapan variable tersebut terhadap ROA dalam penelitian ini sebesar 12,9\%, sedangkan sisanya dipengaruhi factor lain yang tidak dimasukkan ke dalam model penelitian.

Anam (2009) tujuan penelitian ini adalah sebagai penelitian lanjutan untuk mengetahui dan menjelaskan tentang pengaruh Asset Libaility Management terhadap kinerja Bank Muamalat Indonesia dan Bank Mandiri tahun 2004-2006 sekaligus untuk mengetahui perbedaan tingkat profitabilitas dilihat dari ROA diantara kedua bank tersebut. Metode yang digunakan adalah Regresi Linier Berganda. Variabel yang digunakan dalam penelitian ini meliputi ROA, CR, COR, dan CAR. Hasil kesimpulan dari penelitian ini diketahui bahwa, tingkat likuiditas CR tidak berpengaruh signifikan terhadap profitabilitas (ROA) pada Bank Muamalat Indonesia dan Bank Mandiri. Tingkat COR berpengaruh signifikan terhadap tingkat profit (ROA) Bank Mandiri, tetapi tidak berpengaruh signifikan pada profit Bank Muamalat Indonesia. Tingkat Likuiditas CAR tidak berpengaruh signifikan terhadap ROA pada Bank Muamalat Indonesia dan Bank Mandiri. CR, COR, CAR secara bersama sama, berpengaruh signifikan terhadap variabel ROA pada Bank Muamalat Indonesia dan Bank Mandiri. Bank Muamalat lebih baik dalam menghasilkan profit di bandingkan Bank Mandiri.

Ningsih (2012) penelitian bertujuan untuk melakukan perbandingan kinerja keuangan Bank Umum Syariah dengan Bank Umum Konvensional di Indonesia pada periode 2006-2010 dengan menggunakan rasio keuangan. Variabel yang digunakan adalah CAR, LDR, NPL, BOPO, ROA. Metode yang digunakan adalah Independent Sample Ttest. Hasil analisis menunjukkan bahwa terdapat perbedaan yang signifikan untuk masing-masing rasio keuangan antara Bank Umum Syariah dengan Bank Umum Konvensional di Indonesia. Bank Umum Syariah lebih baik kinerjanya dari segi LDR dan ROA, sedangkan Bank Umum Konvensional lebih baik kinerjanya dari segi rasio CAR, NPL, dan BOPO.

Astari (2013) penelitian ini mengambil objek Bank Muamalat Indonesia dan Bank UOB Indonesia sebagai bank konvensional. Variabel yang digunakan terdiri dari Cash Ratio, Reserve Requirement, LDR, Loan to Asset Ratio, BOPO, NPM, ROA, ROE, DER, dan CAR. Metode yang digunakan adalah uji independent Sample T-test. Hasil penelitian secara keseluruhan dari rasio keuangan yang digunakan memperlihatkan kinerja keuangan yang fluktuatif. Berdasarkan hasil uji statistic dari 5 variabel Cash Ratio, Reserve Requirment, LDR, ROE, dan DER menunjukkan kinerja keuangan Bank Muamalat Indonesia lebih baik dibandingkan kinerja keuangan Bank UOB Indonesia, sedangkan Loan to Asset Ratio, BOPO, NPM, ROA, dan CAR menunjukkan kinerja keuangan Bank UOB Indonesia lebih baik dibandingkan kinerja keuangan Bank Muamalat Indonesia. Kemudian pada uji Independent Sample T-test menunjukkan terdapat perbedaan yang 
Jurnal Ekonomi dan Perbankan Syariah

Vol. 3. No.1, April 2015: 1-17, ISSN (cet): 2355-1755

signifikan kinerja keuangan Bank Muamalat Indonesia dengan kinerja keuangan Bank UOB Indonesia dilihat dari Cash Ratio, Reverse Requirement, BOPO, NPM, ROA, DER, CAR, sedangkan dari LDR, Loan to Asset Ratio, ROE menujukkan tidak terdapat perbedaan yang signifikan antara kinerja keuangan Bank Muamalat Indonesia dengan kinerja keuangan UOB Indonesia.

Suwanto (2011) penelitian dilakukan untuk mendapatkan bukti empiris mengenai perbedaan kinerja keuangan perbankan syariah dengan pendekatan laba rugi dan nilai tambah dilihat dari beberapa variabel rasio ROA, ROE, rasio perbandingan antara total laba bersih dengan total aktiva produktif, NPM dan BOPO. Metode yang digunakan adalah pendekatan Income Statement Approach dan Value Added Approach. Berdasarkan hasil pengujian hipotesis menunjukka bahwa rata-rata rasio ROA, ROE, rasio perbandingan antara total laba bersih dengan total active produktif, NPF dan BOPO berbeda secara signifikan antara pendekatan laba rugi dengan pendekatan nilai tambah. Demikian juga dengan kinerja keseluruhan.

Berdasar pemaparan penelitian sebelum diatas dapat diringkas dalam tabel 2.2 dibawah ini:

Tabel 2. 2 Penelitian Terdahulu pada Bank Umum Syariah

\begin{tabular}{|c|c|c|c|c|}
\hline \multirow{2}{*}{ Nama } & \multicolumn{4}{|c|}{ Variabel } \\
\cline { 2 - 5 } & CAR & NPF & BOPO & FDR \\
\hline Dewi (2010) & X & $\sqrt{ }$ & - & X \\
\hline Setiawan (2009) & $\sqrt{ }$ & $\sqrt{ }$ & $\sqrt{ }$ & $\sqrt{ }$ \\
\hline Anam (2009) & $\mathrm{X}$ & - & - & - \\
\hline Ningsih (2012) & $\mathrm{X}$ & - & $\mathrm{X}$ & - \\
\hline Astari (2013) & $\mathrm{X}$ & - & $\mathrm{X}$ & - \\
\hline Suwanto (2011) & - & $\sqrt{ }$ & $\sqrt{ }$ \\
\hline
\end{tabular}

Sesuai dengan penelitian terdahulu yang telah dipaparkan ada beberapa faktor rasio yang akan dijadikan bahan penelitian ini yaitu Capital Adequecy Ratio (CAR), Non Performing Financial (NPF), Return On Asset (ROA), Biaya Operasional terhadap Pendapatan Operasional (BOPO), Financing Deposit to Ratio (FDR).

Hipotesis menyatakan hubungan yang diduga secara logis antara dua variabel atau lebih dalam rumusan proporsi yang dapat diuji secara empiris. Hipotesis dalam penelitian kuantitatif dikembangkan dari telaah teoritis sehingga jawaban sementara dari masalah atau pernyataan memerlukan pengujian empiris.

Hipotesis yang dapat diajukan dalam penelitian ini adalah :

$\mathrm{H}_{1}$ : Variabel CAR berpengaruh positif dan signifikan terhadap profitabilitas BMI

$\mathrm{H}_{2}$ : Variabel BOPO berpengaruh negatif terhadap profitabilitas BMI

$\mathrm{H}_{3}$ : Variabel NPF berpengaruh negatif dan signifikan terhadap profitabilitas BMI

$\mathrm{H}_{4}$ : Variabel FDR berpengaruh negatif dan signifikan terhadap profitabilitas BMI

\section{METODE PENELITIAN}

\section{Jenis Dan Sumber Data}

Jenis data yang digunakan dalam penelitian ini adalah data kuantitatif berupa laporan keuangan yang publikasi tahunan yang diterbitkan oleh Bank Muamalat Indonesia selama empat belas tahun berturut-turut dari periode tahun 2000 sampai 
dengan tahun 2014. Sumber data yang digunakan ini diperoleh melalui penelusuran dari media internet dan website resmi Bank Muamalat Indonesia. Sumber penunjang lainnya berupa jurnal yang diperlukan, beberapa buku penunjang dan sumber-sumber lainnya yang dapat digunakan dalam penelitian ini.

\section{Metode Analisis}

\section{Uji Stasioneritas}

Uji stasioner sangat penting bagi data time series dan uji ini dilakukan sebelum data dianalisis. Sekumpulan data dikatakan stasioner jika nilai rata-rata dan varian dari data time series tersebut tidak mengalami perubahan secara sistematik sepanjang waktu sehingga data tersebut konstan. Uji stasioner data ini dapat dilakukan dengan menggunakan Augmanted Dickey-Fuller (ADF) pada derajat yang sama (level atau different) hingga diperoleh suatu data yang stasioner, yaitu data yang variannya tidak terlalu besar dan mempunyai kecenderungan untuk mendekati nilai rata-ratanya (Enders, 1995 dikutip oleh Primanti, 2011). DF test digunakan ketika asumsi bahwa eror term $\left(u_{t}\right)$ tidak saling berkolerasi. Namun ketika $u_{t}$ saling berkolerasi, maka kita menggunakan ADF Test. Tes ini dilakukan dengan menambah (augmenting) nilai lag pada variabel dependen. Secara spesifik, tes ADF mengikuti persamaan dibawah ini (Gujarati, 2003: 817 dikutip oleh Primanti, 201: 165)

$$
\Delta Y_{t}=\alpha_{0}+\gamma Y_{t-1}+\beta_{i} \sum_{i=1}^{p} \Delta Y_{t-i+1}+\varepsilon_{t}
$$

Dimana :

$$
\begin{array}{ll}
\mathrm{Y}_{\mathrm{t}} & \text { : Bentuk dari first difference } \\
\alpha_{0} & : \text { Intersep } \\
\mathrm{Y} & : \text { Variabel yang diuji stasioneritasnya } \\
\mathrm{P} & : \text { Panjang lag yang digunakan pada model } \\
\varepsilon & : \text { Error term }
\end{array}
$$

\section{Uji Lag Length}

Uji lag length bertujuan untuk mengetahui lag optimal yang digunakan dalam model penelitian. Hal ini dikarenakan jika lag yang digunakan terlalu sedikit, maka residual dari regresi tidak akan menampilkan proses white noise sehingga model tidak dapat mengestimasi actual error secara tepat. Akibatnya standar kesalahan tidak diestimasi secara baik. Selain itu jika memasukan lag terlalu banyak akan mengurangi kemampuan menolak Ho dan dapat mengurangi derajat kebebasan.

\section{Uji Kausalitas Granger}

Uji kausalitas granger bertujuan untuk melihat apakah suatu variabel mempunyai hubungan dua arah atau hanya satu arah saja. Pada uji ini yang dilihat adalah pengaruh masa lalu terhadap kondisi sekarang, sehingga data yang digunakan adalah data time series. Hubungan kausalitas antar variabel menggunakan nilai probabilitasnya. Jika nilai probabilitas masing-masing variabel lebih kecil daripada nilai $\alpha$, maka dapat dinyatakan terdapat hubungan kausalitas antar variabel. Begitupun sebaliknya, jika nilai probabilitas lebih besar dari 0,05 maka tidak terdapat hubungan kausalitas antar variabel.

\section{Uji Kointegrasi}

Uji kointegrasi bertujuan untuk menentukan apakah variabel-variabel yang tidak stasioner terkointegrasi atau tidak. Konsep kointegrasi dikemukakan oleh Engle dan 
Jurnal Ekonomi dan Perbankan Syariah

Vol. 3. No.1, April 2015: 1-17, ISSN (cet): 2355-1755

Granger (1987) sebagai kombinasi linear dari dua arah atau lebih variabel yang tidak stasioner akan menghasilkan variabel yang stasioner. Kombinasi linear ini dikenal dengan istilah persamaan kointegrasi dan dapat diinterpretasikan sebagai hubungan keseimbangan jangka panjang di antara variabel (Firdaus, 2011)

Uji kointegrasi dilakukan untuk mendeteksi stabilitas hubungan jangka panjang dua variabel atau lebih. Kointegrasi adalah suatu hubungan jangka panjang atau ekuilibrium antara variabel-variabel yang tidak stasioner. Dengan kata lain, walau secara individual variabel-variabel tersebut tidak stasioner, namun kombinasi antar variabel tersebut bisa menjadi stasioner. Jika nilai Trace Statistic-nya lebih kecil dibanding nilai kritis pada tingkat keyakinan 5\% maupun 1\% dapat disimpulkan bahwa antar variabel tidak saling berkointegrasi.

\section{Estimasti Vecm}

Berdasarkan tujuan analisis VECM yaitu untuk mengetahui tingkah laku jangka pendek dari suatu variabel terhadap jangka panjangnya, akibat adanya shock (perubahan) yang permanen, maka estimasi yang dapat digunakan sebagai bentuk dari persamaan sebelumnya dengan membaca hasil olahan data. Dimana, jika nilai t-statistik hasil estimasi lebih besar daripada nilai t-tabelnya, maka dapat dikatakan terdapat hubungan jangka panjang atau jangka pendek. Sedangkan, jika nilai t-statistiknya hasil estimasi lebih kecil daripada nilai t-tabelnya, maka dapat dikatakan tidak terdapat hubungan jangka panjang atau jangka pendek..

\section{HASIL DAN ANALISIS}

\section{Uji Stasioneritas}

Tabel 4. 1 Hasil Pengujian Akar Unit Pada Level

\begin{tabular}{|c|l|c|c|c|c|}
\hline \multirow{2}{*}{ Variabel } & \multirow{2}{*}{ Nilai ADF } & \multicolumn{3}{|c|}{ Nilai Kritis Mackinnon } & \multirow{2}{*}{ Prob* $^{*}$} \\
\cline { 3 - 5 } & & $\mathbf{1 \%}$ & $\mathbf{5 \%}$ & $\mathbf{1 0 \%}$ & \\
\hline ROA & -4.578 & -4.133 & -3.493 & -3.175 & $0.0028^{*}$ \\
\hline CAR & -3.676 & -4.133 & -3.493 & -3.175 & $0.0324^{*}$ \\
\hline BOPO & -3.344 & -4.133 & -3.493 & -3.175 & 0.0699 \\
\hline FDR & -5.329 & -4.137 & -3.495 & -3.176 & $0.0003^{*}$ \\
\hline NPF & -4.458 & -4.137 & -3.495 & -3.176 & $0.0041^{*}$ \\
\hline
\end{tabular}

* : data stasioner pada taraf 5\%

Sumber : Output Eviews 8 (data di olah)

Hasil uji stasioneritas data pada level menunjukkan bahwa semua yang bertanda bintang menyatakan bahwa semua variabel stasioner kecuali BOPO yang tidak stasioner pada taraf nyata $5 \%$, dapat diartikan bahwa BOPO belum stasioner pada uji unit root tingkat level. Hal ini dikarenakan nilai mutlak t-ADF lebih kecil dari nilai mutlak Mackinnon Critical Values-nya pada taraf nyata 5\%. Penelitian dengan data yang tidak stasioner dapat menghasilkan regresi palsu (spurious regression). Karena itu, uji stasionaritas dapat dilanjutkan pada tingkat first difference. Pada Tabel 4.1 terlihat bahwa variabel BOPO nilai probabilitasnya lebih besar dari taraf nyata 5\%, untuk itu akan dilakukan uji tingkatan selanjutnya yaitu Uji First Difference. Namun jika salah satu variabel stasioner di tingkat first difference, maka semua variabel harus stasioner di tingkat first difference. 
Berdasarkan hasil pengujian akar unit pada Tabel 4.1 sebelumnya bahwa tidak semua variabel stasioner pada tingkat level, maka dari itu dilanjutkan dengan pengujian akar unit pada tingkat first difference. Menurut Tabel 4.2 pada pengujian akar unit pada first difference dapat dilihat bahwa nilai probabilitas pada tingkat diferensiasi 1 yaitu ROA sebesar 0.000, CAR sebesar 0.000, BOPO sebesar 0.000, FDR sebesar 0.000, dan NPF sebesar 0.000 , dimana hal itu menunjukkan bahwa nilai probabilitas kelima variabel tersebut lebih kecil dari 0.05 atau 5\% dan nilai ADF-nya lebih besar dibandingkan nilai Mackinnon, sehingga $\mathrm{H}_{\mathrm{o}}$ ditolak. Hal tersebut menjelaskan bahwa variabel ROA, CAR, BOPO, FDR, dan NPF stasioner dengan tingkat diferensiasi 1.

Tabel 4. 2 Hasil Pengujian Akar Unit Pada First Difference

\begin{tabular}{|c|c|c|c|c|c|}
\hline \multirow{2}{*}{ Variabel } & \multirow{2}{*}{ Nilai ADF } & \multicolumn{2}{|c|}{ Nilai Kritis Mackinnon } & \multirow{2}{*}{ Prob* } \\
\cline { 3 - 5 } & & $\mathbf{1 \%}$ & $\mathbf{5 \%}$ & $\mathbf{1 0 \%}$ & \multirow{2}{*}{} \\
\hline ROA & -7.374 & -4.140 & -3.496 & -3.177 & 0.000 \\
\hline CAR & -8.615 & -4.137 & -3.495 & -3.176 & 0.000 \\
\hline BOPO & -9.999 & -4.137 & -3.495 & -3.176 & $0.000^{*}$ \\
\hline FDR & -9.883 & -4.137 & -3.495 & -3.176 & 0.000 \\
\hline NPF & -7.410 & -4.144 & -3.498 & -3178 & 0.000 \\
\hline
\end{tabular}

* : BOPO telah stasioner pada tingkat first deffernce

Sumber : Output Eviews 8 (data di olah)

\section{Uji Lag Length}

Dalam model VAR penentuan Lag Length sangat berguna untuk menghilangkan autokolerasi. Berdasarkan Tabel 4.3 dapat dilihat hasil lag yang akan digunakan untuk model selanjutnya yaitu lag 1 . Hal ini dikarenakan nilai SC dan HQ terkecil diantara lag yang lainnya. Meskipun nilai AIC berada pada lag 7 namun dalam penelitian ini digunakan lag 1 sebagai lag optimun. Sedangkan AIC berada pada lag 7 yang berbeda dengan model SIC dan HQ untuk lag optimumnya. Hal ini dikarenakan apabila menggunakan AIC sebagai lag optimun data, sedangkan SIC dan HQ berada pada lag optimum 1 maka yang dihasilkan adalah tidak dapat dioutputnya hasil estimasi VECM pada lag optimum 7 oleh progam Eviews 8. Oleh karena itu lag optimum yang digunakan adalah lag 1 bertanda bintang pada SC dan HQ yang menyatakan sebagai lag optimum karena paling kecil.

Tabel 4. 3 Hasil Pengujian Lag Lenght

\begin{tabular}{|c|c|c|}
\hline Lag & SC & HQ \\
\hline 0 & -22.9529 & -22.8797 \\
\hline 1 & $-23.2586^{*}$ & $-23.9774^{*}$ \\
\hline 2 & -22.3337 & -23.6516 \\
\hline 3 & -21.1544 & -23.0713 \\
\hline
\end{tabular}

* : menunjukkan angka terkecil; Sumber : Output Eviews 8 (data di olah);

Keterangan : SC : Schwarz Information Criterion; HQ : Hannan-Quinn Information Criterion

Dari hasil Tabel 4.3 di atas, diketahui bahwa tanda yang berbintang berada pada lag 1. Hal ini menunjukkan bahwa lag optimal yang direkomendasikan Eviews adalah lag 1. Bahwa yang paling kecil dan lagnya optimal hanya SC dan HQ, apabila menggunakan terlalu banyak misal hingga lag tujuh maka data yang diperoleh dari hasil pengolahan tidak akan optimal. 
Jurnal Ekonomi dan Perbankan Syariah

Vol. 3. No.1, April 2015: 1-17, ISSN (cet): 2355-1755

\section{Uji Derajat Koentegrasi}

Semua variabel telah stasioner pada tingkat first difference, sehingga uji kointegrasi melalui Johansen Cointegration Test dapat dilakukan.

Tabel 4. 4 Hasil Pengujian Derajat Kointegrasi

\begin{tabular}{|c|c|c|c|}
\hline $\begin{array}{c}\text { Hypothesized } \\
\text { No. Of CE(s) }\end{array}$ & Eigenvalue & Trace Statistic & $\mathbf{5 \%}$ Critical Value \\
\hline None* $^{*}$ & 0.64219 & 123.8629 & 88.8038 \\
\hline At most $1^{*}$ & 0.43077 & 68.3646 & 63.8761 \\
\hline At most 2 & 0.32923 & 37.9370 & 42.9152 \\
\hline At most 3 & 0.201567 & 16.3729 & 25.8727 \\
\hline Atmost 4 & 0.075125 & 4.2172 & 12.5179 \\
\hline
\end{tabular}

* : menunjukkan signifikan pada taraf 5\%

Sumber : Output Eviews 8 (data di olah)

Berdasarkan Tabel 4.4 dapat dilihat bahwa nilai Trace Statistic sebesar 123,8629 lebih besar dibandingkan dengan nilai kritis pada tingkat keyakinan 5\% yaitu sebesar 88.80380, dengan menggunakan taraf nyata sebesar 5\% terdapat 2 persamaan yang terkointegrasi yaitu yang bertanda bintang pada tabel 4.4 diatas. Hal tersebut menunjukkan bahwa terjadi kointegrasi antarvariabel pada tingkat keyakinan $5 \%$ atau 0,05 . Terdapat 2 persamaan yang terkointegrasi, hal tersebut dapat dilihat saat nilai Trace Statistic > Critical Value. Sehingga dapat dilanjutkan ke model VECM untuk mendapatkan informasi mengenai terdapatnya persamaan yang terkointegrasi.

\section{Uji Kausalitas Granger}

Hasil uji kausalitas granger adalah yang terangkum pada Tabel 4.5 hasil uji ini menunjukkan bahwa tidak terdapat hubungan dua arah diantara variabel. Dimana semua variabel yang diamati hanya memiliki hubungan kausalitas satu arah.

Tabel 4. 5 Hasil Pengujian Kausalitas Granger

\begin{tabular}{|c|c|}
\hline Null Hypothesis & Probability \\
\hline CAR does not Granger Cause BOPO & 0.5242 \\
\hline NPF does not Granger Cause BOPO & 0.2556 \\
\hline FDR does not Granger Cause BOPO & 0.1581 \\
\hline ROA does not Granger Cause BOPO & 0.0932 \\
\hline NPF does not Granger Cause CAR & 0.0134 \\
\hline FDR does not Granger Cause CAR & 0.4604 \\
\hline ROA does not Granger Cause CAR & 0.3457 \\
\hline FDR does not Granger Cause NPF & 0.7239 \\
\hline ROA does not Granger Cause NPF & 0.2011 \\
\hline ROA does not Granger Cause FDR & 0.3711 \\
\hline
\end{tabular}

Sumber : Output Eviews 8 (data diolah)

Dapat diketahui bahwa secara Granger CAR mempengaruhi BOPO, NPF mempengaruhi BOPO, FDR mempengaruhi BOPO, ROA mempengaruhi BOPO, NPF mempengaruhi CAR, FDR mempengaruhi CAR, ROA mempengaruhi CAR, FDR mempengaruhi NPF, ROA mempengaruhi NPF, ROA mempengaruhi FDR. 


\section{Estimasi Vecm}

Berdasarkan tujuan analisis VECM yaitu untuk mengetahui tingkah laku jangka pendek dari suatu variabel terhadap jangka panjangnya, akibat adanya shock (perubahan) yang permanen, maka estimasi yang dapat digunakan sebagai bentuk dari persamaan sebelumnya dengan membaca hasil olahan data. Dimana, jika nilai t-statistik hasil estimasi lebih besar dari pada t-tabel, maka dapat dikatakan terdapat hubungan jangka panjang ataupun jangka pendeknya. Sedangkan jika nilai t-statistik hasil estimasi lebih kecil dari pada t-tabel maka dapat dikatakan tidak terdapat hubungan jangka panjang maupun jangka pendeknya.

Tabel 4. 6 Hasil Pengujian VECM Jangka Panjang

\begin{tabular}{|c|c|c|}
\hline \multicolumn{3}{|c|}{ Jangka Panjang } \\
\hline Variabel & Koefisien & T-Statistik \\
\hline CAR(-1) & 94.4944 & -5.68681 \\
\hline BOPO(-1) & 23.72776 & $-2.72985^{*}$ \\
\hline NPF(-1) & 63.01761 & $-411314^{*}$ \\
\hline FDR(-1) & 23.63644 & $-538673^{*}$ \\
\hline C & 57.51919 & - \\
\hline
\end{tabular}

Sumber : Output Eviews 8 (data diolah)

Estimasi VECM dilakukan untuk melihat adanya hubungan jangka pendek dan jangka panjang (Fatmawati, 2014). Pada jangka pendek terdapat koreksi kesalahan sebesar 0.001129 , hal ini mengindikasikan untuk menuju keseimbangan jangka panjang diperlukan koreksi sebesar 0.00129 persen. Dapat terlihat pada lampiran hasil output VECM pada C urutan D(DROA) pada baris ke-dua yang menerangkan bahwa koreksi kesalahan yang dihasilkan adalah 0.00129 persen. Sedangkan pada baris pertama pada lampiran hasl output VECM adalah konstanta, dan pada baris ketiganya merupakan nilai t-statistiknya.

Tabel 4. 7 Hasil Pengujian VECM Jangka Pendek

\begin{tabular}{|c|c|c|}
\hline \multicolumn{3}{|l|}{ Jangka Pendek } \\
\hline Variabel & Koefisien & T-statistik \\
\hline CointEq1 & 0.0007 & -1.68229 \\
\hline $\mathrm{D}(\mathrm{ROA}(-1))$ & 0.5933 & -3.98055 \\
\hline $\mathrm{D}(\mathrm{CAR}(-1))$ & 0.0620 & -1.19701 \\
\hline $\mathrm{D}(\mathrm{BOPO}(-1))$ & 0.0774 & $-2.41142^{*}$ \\
\hline $\mathrm{D}(\mathrm{NPF}(-1))$ & 0.0141 & 0.21619 \\
\hline $\mathrm{D}(\mathrm{FDR}(-1))$ & 0.0289 & $-2.23855^{*}$ \\
\hline $\mathrm{C}$ & 0.0009 & 0.80292 \\
\hline
\end{tabular}

* : signifikan pada taraf $5 \%$ dengan $t$-tabel sebesar 2.000

Sumber : Output Eviews 8 (data diolah)

Berdasarkan dari tabel 4.7 dapat dilihat hasil pengujian pada VECM pada jangka pendek pada tanda yang berbintang menunjukkan signifikasi bahwa t- statistik lebih besar dari pada t-tabel yang menyatakan bahwa BOPO memengaruhi ROA secara signifikan yaitu sebesar -2.41142. Artinya, apabila terjadi kenaikan pada BOPO sebesar satu persen maka ROA menurun sebesar 2.41142 persen. FDR memengaruhi ROA secara 
signifikan yaitu sebesar -2.23855 . Artinya, apabila terjadi kenaikan pada FDR sebesar satu persen, maka ROA akan menurun sebesar 2.23855 persen.

Pada tabel 4.6 didapatkan hasil estimasi VECM pada jangka panjang menunjukkan bahwa CAR tidak mempengaruhi profitabilitas BMI secara signifikan. Hasil ini sama dengan hasil penelitian pada Bank Muamalat Indonesia dari Arianti (2011) yang menyatakan bahwa CAR tidak berpengaruh signifikan terhadap profitabilitas dan pembiayaan. Dahlia (2012) menyatakan bahwa CAR tidak berpengaruh signifikan terhadap profitabilitas, hal tersebut dikarenakan adanya perbandingan antara kinerja bank konvensional terhadap bank syariah. Widodo (2014) menyatakan bahwa CAR tidak berpengaruh terhadap profitabilitas. Pada bank syariah lainnya seperti hasil penelitian dari Dewi (2010), Anam (2009), Ningsih (2012), Astari (2013) yang menyatakan bahwa CAR tidak berpengaruh signifikan terhadap profitabilitas. Hal ini dapat terjadi dikarenakan adanya perbandingan antara bank konvensional dan bank syariah, serta perbedaan dari masing-masing metode dan variabel yang digunakan pada masing-masing penelitian.

Namun berbeda dengan hasil penelitian pada Bank Muamalat Indonesia dari Amsaroh (2012), Pratiwi dan Astutiningsih (2009), Martadireja (2014), Maharani (2010), Akhirudin (2014), Rosada (2013), dan Puspitasari (2009) menyatakan bahwa CAR berpengaruh negatif dan signifikan terhadap profitabilitas. Begitu pula dengan hasil penelitian terdahulu pada bank syariah selain BMI dari Setiawan (2009) menyatakan bahwa CAR berengaruh positif dan signifikan terhadap profitabilitas. Ini terjadi dikarenakan perbedaan metode dan variabel yang digunakan pada masing-masing penelitian. Dapat diartikan dari hasil penelitian jika terjadi kenaikan CAR sebesar satu persen maka profitabilitas Bank Muamalat akan menurun sebesar 5,68681 persen.

Hasil estimasi VECM pada jangka panjang menunjukkan bahwa BOPO berpengaruh negatif dan signifikan terhadap profitabilitas. Penelitian ini sama halnya dengan penelitian terdahulu pada Bank Muamalat Indonesia yaitu Pratiwi dan Astutiningsih (2009), Dahlia (2012), Maharani (2010), Akhirudin (2014), Widodo (2014) dan Puspitasari (2009) menyatakan bahwa BOPO berpengaruh negatif dan signifikan terhadap profitabilitas. Lain dengan hasil penelitian Damastuti (2010) yang menyatakan bahwa BOPO tidak berpengaruh signifikan terhadap profitabilitas bank tersebut.

Namun pada bank syariah selain BMI yang menyatakan hasil penelitian yang sama yaitu hasil dari Setiawan (2009) dan Suwanto (2011) yang menyatakan bahwa BOPO berpengaruh negatif dan signifikan terhadap profitabilitas bank tersebut. Berbeda lagi dengan pendapat yang dihasilkan dari penelitian Ningsih (2012) dan Astari (2013) yang menyatakan bahwa BOPO tidak memiliki pengaruh terhadap profitabilitasnya. Dari hasil yang dapat disimpulkan bahwa terjadi perbedaan hasil pada variabel BOPO akibat dari perbedaan metode dan jumlah variabel yang digunakan pada masing-masing penelitian. Dapat diartikan dari hasil penelitian yang telah dilakukan bahwa jika terjadi pada BOPO sebesar satu persen maka profitabilitas pada BMI akan menurun sebesar 2.72985 persen.

Hasil estimasi VECM pada jangka panjang menunjukkan bahwa NPF berpengaruh negatif dan signifikan terhadap profitabilitas BMI. Hasil penelitian ini sama dengan hasil penelitian sebelumnya pada BMI yang dihasilkan oleh Amsaroh (2012), Martadireja (2014), dan Rosada (2013) yang menyatakan bahwa NPF berpengaruh negatif dan 
signifikan terhadap profitabilitas dengan menggunakan metode yang berbeda-beda pada masing-masing hasil penelitiannya. Berbeda dengan hasil penelitian dari Arianti (2011) dan Akhirudin (2014) yang menyatakan bahwa NPF tidak berpengaruh signifikan terhadap profitabilitas, ini dikarenakan metode yang digunakan berbeda-beda pada setiap penelitian yang dilakukan.

Namun pada bank syariah lainnya selain BMI menurut Dewi (2010), Setiawan (2009) dan Suwanto (2010) menyatakan bahwa NPF berpengaruh negatif dan signifikan terhadap profitabilitas bank syariah. Hal ini terjadi dikarenakan perbedaan metode dan variabel yang digunakan pada masing-masing penelitian. Dapat diartikan dalam penelitian bahwa jika terjadi kenaikan NPF sebesar satu persen maka profitabilitas BMI akan menurun sebesar 4.11314 persen.

Hasil estimasi VECM pada jangka panjang menunjukkan bahwa FDR berpengaruh negatif dan signifikan terhadap profitabilitas BMI. Hasil penelitian ini sama dengan hasil penelitian terdahulu pada BMI dari Amsaroh (2012), Dahlia (2012), Widodo (2014) dan Rosada (2013) yang menyatakan bahwa FDR berpengaruh negative dan signifikan terhadap profitabilitas BMI dengan metode dan variabel yang berbeda pada masingmasing penelitian. Berbeda dengan pendapat Maharani (2010) dan Akhirudin (2014) menyatakan bahwa FDR tidak berpengaruh signifikan terhadap profitabilitas BMI dengan menggunakan metode dan variabel yang berbeda setiap penelitiannya.

Namun pada bank syariah selain BMI ada persamaan penelitian yang dihasilkan dari penelitian sebelumnya yaitu Setiawan (2009) yang menyatakan bahwa FDR berpengaruh negative dan signifikan terhadap profitabilitas bank syariah tersebut. Sedangkan menurut Dewi (2010) menyatakan bahwa FDR tidak berpengaruh signifikan terhadap profitabilitas bank syariah tersebut. Hal ini dikarenakan metode dan variable yang digunakan berbeda-beda pada setiap penelitian yang dilakukan. Dapat diartikan dari hasil penelitian pada BMi bahwa jika FDR mengalami kenaikan satu persen maka profitabilitas akan menurun sebesar 5.38673 persen.

Hasil pengujian menunjukkan bahwa model koreksi kesalahan dapat dituliskan dengan rumus persamaan sebagai berikut:

$$
\Delta Y=\alpha+B \Delta X_{t-1}+C \Delta X_{t-1}+D \Delta X_{t-1}+\ldots+E C
$$

Sehingga didapatkan persamaan sebagai berikut :

$\Delta \mathrm{ROA}=0.0009-0.5933 \Delta \mathrm{ROA}_{\mathrm{t}-1}-0.0620 \Delta \mathrm{CAR}_{\mathrm{t}-1}-0.0774 \Delta \mathrm{BOPO}_{\mathrm{t}-1}+0.0141 \Delta \mathrm{NPF}_{\mathrm{t}-1}-$

$0.0289 \Delta \mathrm{FDR}_{\mathrm{t}-1}+0.0007 \mathrm{EC}$

Keterangan:

t-1 : menunjukkan waktu atau periode dari waktu sebelumnya

EC : Error Corection

Dari hasil persamaan diatas dapat diketahui signifikan yang ada pada tiap variabel tersebut dapat terlihat pada besarnya t-statistik dengan t-tabelnya, jika t-statistiknya lebih besar dari pada t-tabelnya maka dapat dikatakan bahwa variabel tersebut signifikan (tabel 4.6). Sedangkan untuk mengetahui apakah variabel tersebut berpengaruh atau tidaknya dengan melihat tanda minus ( - ) atau plus (+) pada tabel hasil pengujian. Dan dapat ditarik kesimpulan bahwa CAR tidak berpengaruh signifikan terhadap profitabilitas BMI. Ini berarti $\mathrm{H}_{0}$ diterima dan $\mathrm{H}_{1}$ ditolak, yang berarti hipotesis bahwa CAR berpengaruh positif dan signifikan terhadap profitabilitas BMI tidak terbukti. 
Jurnal Ekonomi dan Perbankan Syariah

Vol. 3. No.1, April 2015: 1-17, ISSN (cet): 2355-1755

Pada variabel BOPO berdasarkan persamaan diatas dihasilkan BOPO berpengaruh negatif dan signifikan terhadap profitabilitas BMI. Hal ini menyatakan bahwa $\mathrm{H}_{0}$ ditolak dan $\mathrm{H}_{2}$ diterima, yang berarti hipotesis bahwa BOPO berpengaruh negatif dan signifikan terhadap profitabilitas BMI terbukti. Selanjutnya pada variabel NPF berdasarkan persamaan yang ada menghasilkan bahwa NPF berpengaruh negatif dan signifikan terhadap profitabilitas BMI. Hal ini menyatakan bahwa $\mathrm{H}_{0}$ ditolak dan $\mathrm{H}_{3}$ diterima, yang berarti hipotesis bahwa NPF berpengaruh negatif dan signifikan terhadap profitabilitas BMI terbukti.

Dan variabel yang terakhir yaitu FDR yang berdasarkan persamaan diatas menyatakan bahwa FDR berpengaruh negatif dan signifikan terhadap profitabilitas BMI. Hal ini menunjukka bahwa $\mathrm{H}_{0}$ ditolak dan $\mathrm{H}_{4}$ diterima, yang berarti hipotesis FDR berpengaruh negatif dan signifikan terhadap profitabilitas BMI terbukti.

\section{SIMPULAN}

Berdasarkan hasil penelitian maka diperoleh beberapa kesimpulan:

a. Hasil VECM jangka pendek diperoleh hasil penelitian bahwa BOPO mempengaruhi profitabilitas secara negatif dan signifikan sebesar -2.41142 , yang berarti jika terjadi kenaikan BOPO sebesar satu persen maka profitabilitas BMI akan menurun sebesar $2.4 \%$ pada jangka pendek. FDR juga memepengaruhi profitabilitas BMI secara negatif dan signifikan sebesar -2.23855, yang berarti jika terjadi kenaikan pada FDR sebesar satu persen maka profitabilitas BMI akan menurun sebesar $2.2 \%$ pada jangka pendek. Sedangkan variabel rasio CAR dan NPF tidak berpengaruh secara signifikan pada profitabilitas BMI pada jangka pendek.

b. Hasil VECM jangka panjang diperoleh hasil penelitian yaitu : (a) CAR tidak berpengaruh signifikan terhadap profitabilitas BMI yang dapat diartikan bahwa jika terjadi kenaikan pada CAR sebesar satu persen maka profitabilitas BMI akan menurun sebesar $5.7 \%$ setiap triwulan. (b) BOPO berpengaruh negatif dan signifikan terhadap BMI, yang dapat diartikan bahwa jika terjadi kenaikan pada BOPO sebesar satu persen maka profitabilitas BMI akan menurun sebesar $2.7 \%$ stiap triwulan. (c) NPF berpengaruh negatif dan signifikan terhadap profitabilitas BMI, yang berarti bahwa jika terjadi kenaikan pada NPF sebesar satu persen maka profitabilitas BMI akan menurun sebesar $4.1 \%$ setiap triwulan. (d) FDR berpengaruh negatif dan signifikan terhadap profitabilitas BMI, yang berarti bahwa jika terjadi kenaikan pada FDR sebesar satu persen maka profitabilitas BMI akan menurun sebesar 5.4\% setiap triwulan.

Berdasarkan pembahasan dan kesimpulan sebelumnya, perlu disampaikan beberapa saran yang berkaitan dengan penelitian ini yaitu: (a) Variabel rasio keuangan yang digunakan dapat ditambahkan lagi dengan rasio keuangan lainnya tergantung dari kebutuhan penelitian. (b) Pada rasio keuangan NIM untuk pebankan syariah jika ingin mengunakan rasio tersebut sebaiknya lebih dipahami terlebih dahulu pengertiannya secara mendalam. Peneliti selanjutnya diharapkan lebih teliti dalam menganalisa data dengan menggunakan metode VECM, bila data yang digunakan pada time series tidak atau kurang baik, sebaliknya menggunakan data panel untuk menunjang hasil penelitian yang lebih maksimal. 


\section{DAFTAR PUSTAKA}

Adyani, Lyla Rahma. (2011). Analisis Faktor-Faktor Yang Mempengaruhi Profitabilitas (ROA). Semarang: Universitas Diponegoro.

Akhirudin, Rohmad. (2014). Analisis Perbandingan Kinerja Keuangan Perbankan Syariah Dengan Perbankan Konvensional (Studi Kasus Pada Bank Muamalat Indonesia dan Bank Tabungan Negara).

Alifah, Y.B. (2014). Pengaruh CAR, NPL, BOPO dan LDR Terhadap Profitabilitas Bank (ROA) Pada Perusahaan Yang Terdaftar di Bursa Efek Indonesia Periode 2009-2012. Yogyakarta: Universitas Negeri Yogyakarta.

Amrizal. (2013). Jurnal Likuidity Vol.2 No.1 Januari-Juni 2013 hlm.13-20. Jakarta: STIE Ahmad Dahlan Jakarta.

Amsaroh, Liya. (2012). Penilaian Tingkat Kesehatan Bank Berdasarkan Faktor Permodalan, Kualitas Aset, Rentabilitas dan Likuiditas PT. Bank Muamalat Indonesia Tahun 2009-2011.

Ananda, Yulia, SE. (2009). Analisis Dampak Krisis Keuangan Global Terhadap Profitabilitas Bank Syariah di PT. Bank Muamalat Indonesia Tbk Periode 2006-2008.

Anam, M. Khairul. (2009). Pengaruh Asset Liability Management Terhadap Kinerja Bank Tahun 2004-2006 (Studi Komparatif Pada PT. Bank Muamalat Indonesia, Tbk dan PT. Bank Mandiri, Tbk).

Antonio, Muhammad Syafi'i. (2001). Bank Syariah Dari Teori Ke Praktek. Jakarta: Gema Insani Press, 2001:34.

Anwar, Ahmad Khairul. (2009). Kinerja Bank Muamalat Indonesia dan Bank Syariah Mandiri. Jakarta: UIN.

Ardiyanto, D. (2012). Analisis Keterkaitan Pengeluaran Pemerintah dan Produk Domestk Bruto Di Indonesia Pendekatan VECM. Jurnal Ilmiah. Malang: Universitas Brawijaya.

Arianti, Wuri N.P. (2011). Ananlisis Pengaruh DPK, CAR, NPF, ROA Terhadap Pembiayaan Pada Perbankan Syariah (Studi Kasus Pada Bank Muamalat Indonesia Periode 20012011).

Arifin, Zainul. (2009). Dasar-dasar Manajemen Bank Syariah. Jakarta: Azka Publisher. Hlm, 63.

Arimi, Millatina. (2012). Analisis Faktor-Faktor Yang Mempengaruhi Perbankan. Semarang: Universitas Diponegoro.

Astari. (2013). Analisis Perbandingan Kinerja Keuangan Bank Syariah Dengan Bank Konvensional (Studi kasus pada PT. Bank Muamalat Indonesia Tbk Dan PT. Bank OUB Indonesia Tbk, Periode 2008-2012). Jambi: Universitas Jambi.

Batuara, Rahman E. 2013. Analisis Pengaruh Return On Asset (ROA) Capital Adequecy Ratio (CAR) Terhadap Harga Saham PT. Bank Negara Indonesia, Tbk. Seminar Penulisan Ilmiah. Jakarta: Universitas Gunadarma.

Burhanudin, Abdullah dan Wimboh Santoso. (2001). The Indonesian Banking Industry: Competition, Consolidation, an System Stability. BIS paper No. 4.

Damastuti, Isnaini Endah. (2010). Analisis Perbandingan Kinerja Keuangan Bank Syariah Dengan Menggunakan Metoe Income Statement Approach dan Value Added Approach (Studi Kasus PT. Bank Muamalat Indonesia Cabang Semarang). Semarang: Universitas Diponegoro.

Devi, Ria Ayu. (2014). Perbandingan Antara Economic Value Added (EVA) Dan Return On Asset (ROA) Dalam Menilai Kinerja Perusahaan. Surakarta: Universitas Muhamadiyah Surakarta.

Dewi, Dhika Rahma. (2010) Faktor-Faktor Yang Mempengaruhi Profitabilitas Bank Syariah di Indonesia.

Dwiastutiningsih, Rini dan wiwit S.P. (2009). Analisis Kinerja Keuangan Pada PT. Bank Muamalat Indonesia, tbk. Krya Ilmiah. Jakarta: Universitas Gunadarma. 
Jurnal Ekonomi dan Perbankan Syariah

Vol. 3. No.1, April 2015: 1-17, ISSN (cet): 2355-1755

Erawati, E. (2014). Analisis Kinerja Keuangan Pada PT.Bank Rakyat Indonesia Syariah. Artikel Publikasi Ilmiah. Surakarta: Universitas Muhamadiyah Surakarta.

Ernawati, Nana. (2011). Pengaruh Kinerja Keuangan Terhadap Tingkat Bagi Hasil Simpanan Mudharabah Pada Bank Muamalat Indonesia Tahun 200-2010. Karya Ilmiah. Yogyakarta: Universitas Muhamaddiyah Yogyakarta.

Fahmi, I. (2014). Pengantar Perbankan Teori dan Aplikasi. Bandung: Alfa Beta.

Firmansyah, I. (2013). Analisis Perbandingan Kinerja Keuangan Bank Muamalat Indonesia dan Bank Syariah Mandiri.

Fatimah, Siti. (2013). Pengaruh Rentabilitas, Efesiensi, dan Likuiditas Terhadap Kecukupan Modal Bank Umum Syariah. Karya Ilmiah.

Fatmawati, Sri wulan dan Irfan Sauqi B. (2014). Pengaruh Indeks Harga Saham Syariah Internasional dan Variabel Makro Ekonomi Terhadap Jakarta Islamic Indeks. Ebook. Bogor: IPB

Handoko, Fredi. (2014) Analisis Kinerja Keuangan Pada PT. Bank Muamalat Indonesia,tbk Periode 2009-2012. Artikel Penelitian. Pontianak: Universitas Tanjungpura.

Hasanah, D. (2012). Analisis Efektivitas Jalur Pembiayaan Dalam Mekanisme Transmisi Kebijakan Moneter Di Indonesia Dengan Metode VECM.

Hardiyanti. (2012). Pengaruh CAR,NPL, dan LDR Terhadap ROA Pada Bank BUMN Yang Go Public di Indonesia (Tahun 2006-2010). Makasar: Universitas Hasanudin.

Hermuningsih, Sri. (2013). Pengaruh Profitabilitas, Growth Opportunity, Struktur Modal Terhadap Nilai Perusahaan Pada Perusahaan Publik di Indonesia.

Hosen, Muhammad N dan M. Faza Firdaus. (2013). Efesiensi Bank Umum Syariah Menggunakan Pendekatan Two-Stage Data Envelopment Analysis. Buletin Ekonomi Moneter dan Perbankan, Oktober 2013.

Husein, S.R. (2012) Analisis Perbandingan Kinerja Keuangan Bank Muamalat Indonesia Dengan Bank Syariah Mandiri. Artikel Ilmiyah. Surabaya: STEI PERBANAS.

Irawati, E.D. (2014). Pengaruh FDR, Pembiayaan Jual Beli, Pembiayaan Bagi Hasil, Pembiayaan Sewa Menyewa, Dan NPF Terhadap Profitabilitas. Semarang: Universitas Diponegoro.

Karimi, K dan Antoni. (2009). Jurnal Ekonomi Bisnis Vol. 11 No. 1 April 2009. Padang: Universitas Bung Hatta.

Machmud, Amir dan Rukmana. (2010). Bank Syariah, Teori, Kebijakan, dan Studi Empiris di Indonesia. Jakarta: Erlangga, 2010: 10-11.

Maharani, Kiki. (2010). Analisis Perbandngan Kinerja Keuangan Perbankan Syariah Dengan Perbankan Konvensional Dengan Menggunakan Rasio Keuangan (PT. Bank Muamalat Indonesia Dengan PT. Bank Rakyat Indonesia Periode 2003-2008).

Mahardian, P. (2008). Analisis Pengaruh Rasio CAR,BOPO,NPL,NIM dan LDR Terhadap Kinaerja Keuangan Perbankan. Tesis. Semarang: Universitas Diponegoro.

Martadireja, Ismaya. (2014). Pengaruh NPF, CAR, NIM Terhadap Profitabilitas Bank (Studi Kasus Pada Bank Muamalat Indonesia Periode 2006-2013).

Muhajir, M. Haris. (2008). Analisis Kointegrasi: Keterikatan Jakarta Islamic Indeks Dengan IHSG dan SBI di Bursa Efek Jakarta. Semarang: Universitas Diponegoro.

Muhammad. (2002). Manajemen Bank Syariah. Yogyakarta: UPP AMP YKPN. HIm. 86

Nainggolan, M.P.P. (2009). Analisis Pengaruh LDR, NIM dan BOPO Terhadap ROA Bank Umum Indonesia. Medan: Universitas Sumatera Utara.

Nasir, M. (2012). Analisis Keterkaitan Ekspor Ke Singapura Terhadap Pertumbuhan Ekonomi Sumatera Utara. Jurnal Mediasi Vol.4 No1 Juni 2012. Medan: Universitas Negeri Medan.

Ningsih, Widya Wahyu. (2012). Analisis Perbandingan Kinerja Keuangan Bank Umum Syariah Dengan Bank Umum Konvensional di Indonesia. 
Nurbaya, F. (2013). Analisis Pengaruh CAR,ROA,FDR Dan Dana Pihak Ketiga (DPK) Terhadap Pembiayaan Murabahah Periode Maret 2001-Desember 2009.

Nurhayati. (2014). Analisis Faktor-Faktor Yang Mempengaruhi Profitabilitas Bank Umum Syariah di Indonesia Tahun 2008-2011. Bengkulu: Universitas Bengkulu.

Nuryartono, N, Ety N, Noer A.A dan Didin H. (2014) Umur dan Kinerja Perusahaan: Studi Empiris Perbankan Syariah Di Indonesia. Jurnal Teknologi Vol.13 No.2 2014. Bogor: Unit Research And Knowledge School of Business- Institut Teknologi Bandung (SBM-ITB).

Pratiwi, D.D. (2012). Pengaruh CAR,BOPO, NPF dan FDR Terhadap ROA Bank Umum Syariah. Semarang: Universitas Diponegoro.

Primanti, M.R, Rahmat H.S, Dyah W.S dan Shochrul R.A. (2011). Cara Cerdas Menguasai Eviews. Jakarta: Salemba Empat.

Priyatno, D. (2008). Mandiri Belajar SPSS. Yogyakarta: Medikom

Purwanto, T.J. (2011) Analisis Besarnya Pengaruh Pembiayaan Financing to Deposit Ratio (FDR dan Non Performing Financing (NPF) Terhadap Laba Bank Syariah. Bogor: IPB

Rosada, N. (2013). Analisis Pengaruh Rasio Keuangan Terhadap Kinerja Keuangan Pada PT. Bank Muamalat Indonesia Tbk. Jurnal Ekonomi dan Informasi Akuntansi (JENIUS) Vol3 No.1 Januari 20913. Lubuklingau: STEI Mura Lubuklingau.

Setiawan, Adi. (2009). Analisis Pengaruh Faktor Makroekonomi, Pangsa Pasar dan Karateristik Bank Terhadap Profitabilitas Bank Syariah (Studi Pada Bank Syariah Periode 2005-2008).

Sukmawijaya, Anita. (2011). Pengaruh Tingkat Suku Bunga Dan Inflasi Terhadap Kinerja Bank Muamalat Indonesia, tbk. Jakarta: Universitas Mercubuana.

Suryani. (2011). Walsongo Vol.19 No.1 ei 2011. Loksemawe.

Suwanto. (2011). Perbandingan Kinerja Keuangan Bank Syariah Dengan Pendekatan Income Statement Apporoach dan Value Added Approach.

Virgowati. (2013). Analisis Kinerja Sosial Perbankan Syariah Di Indonesia. Artikel Publikasi Ilmiyah. Surakarta: Universitas Muhammadiyah Surakarta.

Wibowo, E.S. (2012). Analisis Pengaruh Bunga, Inflasi, CAR, BOPO, NPF Terhadap Profitabilitas Bank Syariah. Semarang: Universitas Diponegoro.

Widyastuti, Sri. (2001). Konsep Keseimbangan dalam Perekonomian Islam. Journal Panutan Bisnis Vol. 4, No. 2. Hal. 142.

Widodo, B. (2014). Perbandingan Kinerja Keuangan PT. Bank Muamalat Indonesia Dengan PT. Bank Mega. Tulung Agung: Institut Agama Islam Negeri.

Yusdani. (2005). Perbankan Syariah Berbasis Floating Market. Journal Millah Vol. IV, No. 2, Januari 2005.

Zulmaita, Ida Syafrida. (2011). Perbandingan Kinerja Keuangan Bank Umum Syariah Dalam Penerapan Peraturan Bank Indonesia. Jurnal Ekonomi Bisnis, Vol. 10, No. 2, Desember 2011:112-126. Jakarta: Politeknik Neger Jakarta.

http://www.bankmuamalat.co.id/investor/laporan-triwulan 